\title{
Ernest Mandel in Resistance: Revolutionary Socialists in Belgium, 1940-1945
}

\section{Jan-Willem Stutje}

Ernest Mandel, the Flemish Marxist theoretician and radical political activist, was enormously influential on the left during the second half of the last century. His writings were published in more than 40 languages in editions of millions of copies. He was the second most translated Belgian author, surpassed only by the novelist Georges Simenon. Mandel was an orator who addressed stadiums filled with audiences of 20,000 people during the Portuguese 'Revolution of Carnations,' and at the same time a celebrated scholar who delivered the prestigious Alfred Marshall Lectures in 1978 at Cambridge University. He wrote a study of the development of the crime novel (Delightful Murder), but also the learned introductions to the Penguin translation of the three volumes of Marx's Das Kapital. On the occasion of his death, the Frankfurter Allgemeine Zeitung commented: "This Belgian political scientist had more anathemas pronounced against him than anyone else, from both the right and the orthodox left.... But for the 1968 generation the name Mandel stood for both a source of inspiration and an example...."1 It is Mandel's lesser-known, politically formative years, however, that provides the focus for this article.

\section{Background}

Many different streams contributed to Mandel's life. The different streams can be summarized in his biography as the tale of a young rebel from a middleclass, Jewish left-wing milieu, whose encounters with a circle of political refugees in the 1930s and during the Nazi occupation, fostered in him a fundamentally internationalist attitude. The milieu of Mandel's parents helped to shape him, and the contacts with German, Austrian, and Polish revolutionary exiles with whom the Mandels associated in Antwerp, enabled him to join the Resistance when German troops occupied Belgian territory. What was the genesis of the left-wing socialist Resistance during the occupation? What kind of politics were promoted? What role did Mandel play in it and how did his attitude change during the Nazi occupation? The answers to these questions can be sought in the impressive archive that Mandel left behind. ${ }^{2}$

Ernest Mandel grew up in an assimilated Jewish environment where religious customs were no longer observed. His father, Henri (Henoch) Mandel, was born on 1 May 1896 to an Orthodox Jewish family in a village, nearby Cracow, then Austrian ruled Poland. The family was not without resources. 
Henri's father owned a textile shop. He encouraged his son to study the Torah but the boy had no interest in a religious education. After finishing high school Henri left in July 1913 for Antwerp to continue his studies in a less religious environment. The outbreak of the World War in August 1914 cut short these plans, and afraid of being called up for service in the Austrian army, Henri left for the Netherlands.

In The Hague he came into contact with young communists, and through them with refugees from Germany. They published a newspaper, Der Kampf (The Struggle), whose contributors included Wilhelm Pieck, who would succeed Ernst Thälmann in 1935 as leader of the Communist Party of Germany (KPD) and become the German Democratic Republic's first president after the Second World War. ${ }^{3}$ When the decisive phase of the German Revolution commenced, Henri Mandel hastened to Berlin. There he helped found the Russian Telegrafen Agentur Rosta: the first Soviet, Russian press bureau and predecessor of the agency Tass. ${ }^{4} \mathrm{He}$ was part of a left-wing intellectual milieu in Berlin and got to know revolutionaries like Karl Radek, who was assisting the German revolutionaries as Lenin's and Trotsky's emissary. The murder of Rosa Luxemburg and Karl Liebknecht in January 1919 shocked Henri so deeply that he fled post-haste back to Antwerp. ${ }^{5}$ While he remained interested in politics, his period of practical involvement came to a temporary end.

He decided to go to work in the diamond industry and met a girl who turned out to be a distant relative of his. They fell in love and a year later Rosa Mateles, as she was called, was pregnant. It was a difficult pregnancy, and on the doctors' advice she decided to give birth to the child in a clinic in Frankfurt-on-Main. There Ernest Ezra Mandel was born on 5 April 1923.

Henri turned out to be a successful businessman. The parents passed on their love for literature, music, and painting to Ernest from an early age. The family had an excellent library that not only included political writings by Marx, Lenin, and Trotsky but also classics of Russian, French, and German literature. At the age of twelve or thirteen Ernest read Victor Hugo's Les Misérables. Hugo's characters embodied a moral ideal, set in the midst of the June 1832 uprising that made young Ernest a socialist. As he later recalled: "My political attitude for the rest of my life was determined then." 6

At the Royal Athenaeum in Antwerp Ernest was a serious student and worked hard. His crowning achievement was his final examination in the summer of 1941 which he passed with over 90 percent of the possible points, and thus stood as not only the best in his class but the best in the whole school; he was awarded the national medal for scholarship and 'the highest distinction'. 


\section{Political Refugees and the Moscow Trials}

Devotion to the muses and his studies were not the only virtues to which Ernest dedicated himself in those years. After Hitler took power, a steady stream of political refugees fled to the countries bordering on Germany, and many came to Antwerp. The Mandel residence welcomed them. As more refugees arrived, Ernest's interest in politics grew. His sympathies were with Trotsky and his followers - it could hardly be otherwise, given the roots of many of the refugees in the Left Opposition - whom Stalin and Hitler were persecuting the most harshly. It was undoubtedly a tragic time, but Ernest felt more excitement than fear; he was getting involved in the intense political activity that was coming to characterize the family.

Yet more and more often evil refused to be ignored, as in Laren, an idyllic artists' colony 20 kilometres southeast of Amsterdam. There, in February 1934, an international youth conference took place as part of the larger movement for a 'new', Fourth International. The deliberations had just begun when the police raided the hall and arrested the foreign delegates, including Willy Brandt (alias Herbert Frahm), Yvan Craipeau, Fritz Besser (alias Brink), and Walter Held. ${ }^{7}$

These events were discussed at length in the Mandel home. The Mandels gave a warm welcome to Besser when he was deported to Belgium. Besser got along well with Ernest. He played the piano exceptionally and gave Ernest piano lessons. All too soon, Ernest felt that he had been practicing scales and études too long. He preferred listening to Besser's impressive political arguments. In his recollections he described Besser as "my best friend" and "teacher". "Even more than my father, he made a Marxist of me."

For Henri and Ernest Mandel the year 1936 was a turning point. Two events made a deep impression on them: the Spanish Civil War and the Moscow Trials. When the Stalinist terror struck thousands of POUM members and anarchists in 1937, the Mandels got involved in broad fundraising efforts. People in the circle around the Mandels had no illusions about the role of Moscow and Moscow-linked communists. Lion Feuchtwanger's expression of approval in January 1937 for the Moscow Trial was for Henri Mandel a sad new low. ${ }^{9}$ Henry had known the defendant Radek well, and was so indignant that he immediately set up a solidarity committee and condemned the cowardice of the generally renowned Feuchtwanger in the publication Der Schutzgeist der Stalinschen Justiz (The Guardian Spirit of the Stalinist Courts).${ }^{10}$ In this way Henri Mandel got involved in the work of the Fourth International. His 13-year-old son turned out to be the most fiery sympathizer, and turned up at all the rallies. Two years later, he was admitted to the Belgian Trotskyist organization (PSR) shortly after the Fourth International's founding conference, which took place in September 1938 in the Paris suburb Périgny. 


\section{May 1940}

On the morning of 10 May 1940, the Mandels were startled by the news of the German advance into the Netherlands and Belgium. Many people were arrested on that 10th of May. Among the internees were close fellow travellers and many key members of the Belgian Communist Party, members of the Flemish fascist VNV and Walloon fascist Rexists, former activists from the 1914-1918 war, and countless foreigners, Germans, and Austrians who had already fled from one country to the next for years. ${ }^{11}$ The Mandels were spared retaliations or suspicion of sabotage. They had Polish citizenship and were not known as communists.

The war had been the main topic of conversation for months. Due to the Molotov-Ribbentrop pact, publication of the Communist daily La Voix $d u$ Peuple (People's Voice) was forbidden in November 1939. The ban also affected the Trotskyist press. In the months before the occupation, revolutionary politics proceeded in an atmosphere of semi-illegality.

The PSR's activities gradually dwindled because, as René Groslambert of the Brussels branch put it, "we felt the war was coming", but "we didn't really know what to do about it". ${ }^{12}$ Belgians in general kept quiet, adopting a waitand-see attitude, and looking towards the government, which preached neutrality and national unity as the only path to salvation.

Ordinary Belgians' lukewarm reaction and the state repression did not fully account for Trotskyists' low spirits. Internal quarrels inside the PSR were also a factor. A spirit of legalism took possession of a part of the organization, deepened by the attitude of Walter Dauge, the leader of the Borinage coal miners' federation. A report that reached the secretariat of the Fourth International bore witness to this:

Since the war began, he [Dauge] has been defending ideas opposed to the unanimous desires of the party. He advocates adapting to the dictatorship.... Don't do anything illegal: that is the kernel of his thinking. He is demoralizing the whole federation. ${ }^{13}$

Dauge rejected out of hand any idea of preparing for underground work. Even before the PSR went underground, it fell apart. Of its 600 members in the Borinage, only a few remained active after 10 May. Dauge gave up on politics, got involved with smuggling and died at a murderer's hand in $1944 .{ }^{14}$

In hindsight Ernest Mandel emphasized that the PSR was morally and politically unprepared to go underground. He attributed this to the group's hybrid character: a cadre organization in Brussels, Antwerp, and Liege, but in the Borinage and Charleroi it was an organization with a 
popular base, that is an organization with roots, members and sympathizers, above all among miners, who inevitably picked up the ideas and concerns of the surrounding environment in which they lived. They were the flesh and blood of the working class; and through this medium, some of the hesitations and demoralization that the war had evoked undeniably found their way into the PSR's ranks. ${ }^{15}$

The malaise lasted almost a year. The organization shrunk to a few dozen members, who barely kept in touch with each other. When the Trotskyists re-established their organization in August 1940, the younger activists, who had joined after 1932 or especially after $1937-38$, took the lead.

\section{The Watchword is Resistance}

Combat ceased in Belgium on 28 May 1940. While the government, Socialist Party (SP), and trade union leaders fled the country, ex-minister and SP Chairperson Hendrik de Man called for co-operation with the occupiers. The communists hesitated about their attitude. They continued to publish a legal newspaper, which mainly criticized the French and English. ${ }^{16}$ The prevailing sentiment on the streets mixed fury at the fleeing Old Guard with tense expectation of what the occupation would bring. These events shocked Ernest Mandel. At the Athenaeum most people were convinced that the Germans would win the war with no further difficulty. ${ }^{17}$ Many political friends had disappeared.

When Belgian newspapers reported the news of Leon Trotsky's murder on about August 21, the news hit like a bomb. Lode Polk, a communist veteran, arrived devastated in Mandel's house. He had known Trotsky personally, corresponded with him, and welcomed him to his house when the Russian revolutionary passed through Antwerp on his way to Norway. ${ }^{18}$ Soon, seven or eight other comrades came to join the group. Together they reached the conclusion that the time for silence had passed; now the watchword was Resistance. In the following days the initiative grew to include about eleven people who had known each other for years, and in early September 1940 formed the 'independent patriotic' Resistance group Vrank en Vrij (Frank and Free). They soon decided to publish a monthly. In late September the first issue of Het Vrije Woord (The Free Word) appeared, stencilled in a print run of 3000 copies on the 'automatic Gestetner duplicating machine' that Henri Mandel bought before the war.

The group around this oldest illegal Flemish-language paper grew to about a hundred members, divided into six branches. The 29-year-old Trotskyist and Spanish Civil War veteran Camille Loots was put in charge of distribution in Brussels. Jean Briquemont, ten years older, took care of members' security and 
led a Resistance group at the Vocational School in Woluwe-Saint-Pierre, where he was headmaster. Marcel Devlieghere knew Henri Mandel from business; he was chief inspector for the Belgian General Insurance Company Ltd. He was one of the group's founders, as were Maurice Spiegel and Cécile Piller, whose cover name was Cylia. Spiegel and Piller were related to Mandel. Cylia, who was single, acted as a courier. In September 1943 she was betrayed to the Gestapo in the Brussels borough Forest. Spiegel had a son at the Athenaeum, who whenever possible, joined Ernest in distributing the paper at school. In 1942, as deportation of Mechelen's Jews gathered speed, the Spiegels tried to flee to unoccupied France. Maurice and his wife were caught, and died at Auschwitz; their son Jan managed to escape, and took part as a member of the Resistance in the liberation of France.

The papers were distributed originally in Antwerp and the surrounding area, mostly in the evening to houses and in shops, but also in post offices, stations, trains, and trams. The four- or sometimes six-page paper could be found as far away as Mechelen and Turnhout. The average print run was barely 5000 copies. After the invasion of the Soviet Union in June 1941 an issue was published in German especially for Wehrmacht soldiers. Four more German editions appeared in the winter months of 1942, the only German-language Resistance publications to appear in Belgium.

There was no explicit, prominent political or ideological vision in Het Vrije Woord; it was an independent anti-Nazi paper, which was passed from hand to hand in a broad political milieu. ${ }^{19}$ This was remarkable given the substantial number of Trotskyists in the group (about 15 percent). In addition Ernest, second only to his father, wrote the lion's share of the articles. Its central idea was the defence of Belgian freedom and independence against the occupier and its quislings, the fascist Rex and VNV. England's ongoing resistance gave the writers "justified hope that not Hitler, but the free peoples, not the Third Reich, but England, France, the USA and probably the Soviet Union as well will have the last word in this world war" ${ }^{20}$ When Mussolini attacked Greece, the 17-year-old Ernest expressed his full conviction that "Britain will come to the aid of the brave Greek people.... This is not only a question of British honour and of the British tradition of loyalty to their friends and allies, but also a means of self-defence in this war against the Axis Powers." ${ }^{21}$ Ernest gave up this perspective long before the British drowned the Greek revolution in blood five years later.

The paper took a clear stand on the first anti-Jewish measures, announced in the occupier's Verordnungsblatt (Gazette) on 6 November 1940. Het Vrije Woord was the first Resistance paper in Antwerp to report them, and warned that the ordinances were "only a beginning", that "Nazi barbarity knows no limits" and that in face of "the brown-black Nazi plague true Belgians [could] only give one answer: sabotage!"22 
Ernest Mandel finished high school in the summer of 1941. His intention to study history at the Free University of Brussels came to nothing, because the professors had almost unanimously suspended their lectures in November as a protest against the appointment of a trio of pro-Nazi teachers. ${ }^{23}$

Since December 1940 the Mandels had been listed in the register of Jews and in June 1942 they were required to wear the Jewish star. They had to pay one franc per strip to receive their three stars in the building on the Belgiëlei where the boys had gone to primary school. The letter J for Jew was stamped on their identity cards with black ink. Eleven days later, on Wednesday, 22 July, the occupiers carried out their first round-ups. The deportees would die in Auschwitz.

It was no secret to Henri Mandel that the Jewish star was the last step before the deportations. He had drawn the conclusion some time before that the "Nazi barbarians" intended to "destroy all Jews to be found under their power"; not only to "persecute them in the most barbarous possible way", but to "systematically exterminate them". ${ }^{24}$ Ernest and his younger brother Michel were told to prepare to go into hiding. Their father sold some valuables, the family jewels and three Austrian carpets, and moved part of the library, some paintings, and other valuable possessions into safekeeping in friends' houses. He also obtained false identity cards under the name Nicolas Jules Robert. The 14year-old Michel, who his parents thought looked too Jewish, was told not to go outside in the daytime. The boys looked for a home for the two parakeets Bibi and Titi, who were used to flying around free in the Cruyslei house.

Many members of Vrank en Vrij were of Jewish origin, and Henri Mandel also moved professionally in largely Jewish circles. He urged everyone to go into hiding and not to report to the Dossin barracks, where the trains left for the East. Rosa's old father and her brother Motek, Orthodox Jews, took to the road in hopes of reaching Switzerland. Maurice Spiegel left with his family, trying to escape to the United States by way of Portugal.

'Don't report, don't report!!' - Jef van der Elst wanted to shout it out. The centre where according to the Arbeitseinsatzbefehl (Employment Order) Jews were supposed to report for transfer to Mechelen was housed on the Pelikaanstraat. Like the Mandels, the Trotskyist docker Van der Elst tried to prevent people from obeying the call. Things went fine for several days, until the Sicherheitsdienst (SD) stormed into the streets. Van der Elst barely managed to get away. ${ }^{25}$ In mid-August the Mandels were on the verge of being arrested. They were warned that the Gestapo was on the trail of the Vrank en Vrij leadership. They decided all at once to leave. They took the Jewish stars off their clothes, and with suitcases in hand Henri, Rosa, and Michel took a train to Brussels. In Tervuren they lodged in a furnished villa that had been rented for the Trotskyist party in order provide temporary hiding places for comrades. While waiting for their false identity cards Rosa and Michel could 
not leave the house. ${ }^{26}$ Once the documents were arranged, they left for a new hiding place in the Ardennes mountains. Henri stayed behind in Brussels, where he prepared to resume publication of Het Vrije Woord. A contact told him that the Gestapo had raided the Cruyslei apartment around 20 December 1942. Were they after the publisher of Het Vrije Woord? Or was the raid part of Operation Möbelaktion (Furniture Action)? ${ }^{27}$ The Germans took with them the part of the library that had not yet been put in safekeeping, about 1400 volumes. They left the house plundered behind them. On the SD file card was written four times: "Disappeared, deleted from Antwerp on 24/3/43". 28

\section{East European Immigrants and International Contacts}

Ernest rarely came home during those months; he was immersed in the Resistance and slept at comrades' homes, mostly around Brussels, Liege, or Charleroi. The PSR recovered from its collapse at the beginning of the occupation; Trotsky's murder encouraged comrades in Antwerp to get the organization going again and they contacted friends in Brussels who felt the same way. ${ }^{29}$ Abram Wajnsztok (alias Abram Leon), Optat Henry (alias Sem), Camille Loots (Cami), and Philippe Szyper (Fraim) pulled the strings.

Wajnsztok, a 22-year-old Pole who was born in Warsaw, played the key role in the group, if not in the whole organization. He settled in Brussels in 1928 with his parents and was active in Hashomir Hatzair (Young Guard), the Socialist-Zionist youth movement founded about the time of the First World War. ${ }^{30}$ In 1939 he left Hashomir Hatzair with other like-minded members and joined the Trotskyists. ${ }^{31}$ His Jewish Question: A Marxist Interpretation, an original analysis of the specificity and continuity of Jewish history, was published posthumously after the war under his alias, Leon. In his introduction to this book, completed in 1942, Ernest Mandel (as Emest Germain) wrote:

When Leon came to international communism, the workers' movement seemed dead in Belgium.... The situation seemed to justify only resignation and watchful waiting. Any other attitude appeared like a manifestation of desperate and impotent revolt. What was lacking was not so much courage to act as courage to think, and to think correctly.... Correctly establishing the reasons which we had for hope, Leon noted that the workers' movement in Europe had already reached the lowest point of its ebb. It was now necessary to count upon a new rise. It was necessary not to await it passively but to prepare for it.... ${ }^{32}$

At the end of the first year of war, new activity began under the impetus of Leon, named political secretary as soon as the reorganization was consoli- 
dated. The group began publishing the monthly La Voie de Lénine (Lenin's Way), edited from Brussels and produced in a small, clandestine print shop, in trunks with false bottoms, in Liege. The paper Travail (Labour) of André Renard's Mouvement syndical unifié (MSU, United Trade-Union Movement) was printed there as well. ${ }^{33}$ The Trotskyists had stayed in touch with Renard, leader of the Liege metal workers, since he had returned from a prisoner-ofwar camp in 1942.

Ernest Mandel met Leon for the first time in Brussels, at a Central Committee meeting of the newly reanimated party. The party was no longer known as the PSR but as the Revolutionary Communist Party (Parti communiste révolutionnaire, PCR). The meeting took place shortly after 22 June 1941, the day that Germany attacked the Soviet Union in the early morning hours.

Many children of Eastern European immigrants found their way to the Trotskyist movement in the late 1930s. Like Leon they had been part of Hashomir Hatzair; branches of this organization were founded in Antwerp and Brussels in the mid-1920s. Second-generation immigrants like Leon, whose integration into non-Jewish society was cut short by the economic crisis and who rejected a return to the traditional Jewish 'street', burst out into impatient rebellion. Preparing to emigrate to Palestine was ultimately incompatible with a life in which poverty and unemployment were common and communism offered an alternative. Radicalization in the early 1930 s mainly benefited the Third International, ${ }^{34}$ but that changed when the German communists proved unable to block Hitler's rise to power. The Comintern's nationalist Popular Front policies and the anti-Semitic Moscow Trials definitively closed the door to these young, radicalizing Jews. While the Antwerp group persisted in its sympathy for Stalin, the Brussels pioneers were open to Trotskyist influence from 1936-37 on. Encouraged by Leon, they joined the ranks of the PCR.

The Jewish group was strengthened from another side. In 1939 Paul Widelin (alias Victor) joined the party after fleeing to Brussels in the same year. Mandel was struck by the audacity of the promising mathematics student: "He didn't seem like a Jewish type, and he took stock of the Germans without complexity. He was already very experienced in clandestine work." 35 Widelin moved to Paris in May 1943, and put out the first issue of the bulletin Arbeiter und Soldat (Worker and Soldier). German soldiers helped distribute the paper until betrayal made the work impossible and the Gestapo murdered Widelin in July $1944 .{ }^{36}$

As soon as the party was back on its feet, Leon began to work on restoring its international ties. Using a reliable connection between Tourcoing and Mouscron, a French delegation showed up for the first time in Brussels in January 1942. The founding meeting of the first European Secretariat secretly took place on a farm owned by the family of Optat Henry (Sem) in St. Hubert in the Ardennes. Along with Sem, Leon and presumably Widelin were there on 
behalf of the Belgians. The unobtrusive Sem, a lecturer at the University of Brussels, had been a member since 1936 .

The meeting devoted most of its attention to the question: what attitude should Trotskyists take to the national question? This question was of great concern to the Belgian revolutionaries as well.

As long as the Nazi regime showed no sign of disintegrating, waiting and seeing rather than taking action seemed the wisest course. Fighting to restore parliamentary democracy was senseless. This was a position that the 45 -yearold Georges Vereeken in particular propagated in the paper Contre le Courant (Against the Current), and that got a certain response inside the PCR. In early 1941 there had still been merger talks between the PCR and the group of 20 or 30 dissident Trotskyists. But in addition to the old pre-war differences - different attitudes towards the Spanish POUM, the policy of 'entryism' (in social democratic parties) and the importance of founding the Fourth International Vereeken's wait-and-see attitude towards Resistance work turned into a stumbling block.

Leon had no use for Vereeken, a Brussels taxi driver, or his short-sighted fatalism. Leon called on Trotskyists to support every form of resistance and build a revolutionary working-class movement. While some critics alleged that the PCR was not free of chauvinistic taints, ${ }^{37}$ Leon could proudly declare to its 1943 congress that not a single social action had taken place in Belgium since 1941 without the party having played a role in it. That was particularly true of the tumult around the closing of the University of Brussels, the 1941 strikes in Liège, and resistance to anti-Jewish measures and deportations.

But despite these encouraging actions, there was no breakthrough. According to Yvan Craipeau, the French member of the European Secretariat who was present at the Belgian congress, the party had too limited a view of the potential for resistance. Mandel wondered too if the PCR would be able to lead the proletariat to victory. ${ }^{38}$ In a document of over 25 closely typed pages, he stressed that everything would depend on the group's organizational capacity. He argued for propaganda efforts to target working-class youth, who had been least affected by the depressing defeats of the past.

Mandel would not stand for reluctance to engage in the proletarian struggle and he rejected those who dismissed resistance to the deportations as Germanophobic or who called a hunger march to German garrison headquarters nationalist. He rejected chauvinistic delusions as a matter of course, but he emphasized that the militants should always support this kind of struggle. All peoples, including Flemings and Walloons, had the right to self-determination, said Mandel, who had yet to reach his 20th birthday. Even if some forces, such as the communist-inspired Independence Front, were struggling for nationalist ends, giving in to them would lead to the absurd conclusion that "the revolutionary struggle and the whole class struggle have to be suspended as long as 
the occupation lasts". Mandel's contribution showed understanding of the workers' movement's theoretical patrimony; he drew on a rich reservoir of historical knowledge and backed up his argument with ready references to Marx, Lenin, Luxemburg, and Trotsky. He was a pedagogue rather than a polemicist or pamphleteer, although he did not avoid that role either. Behind the words was a person who went through life full of self-confidence, with a vitality that now and then bordered on an inflated self-image.

\section{Arrest}

Was it carelessness or underestimation of the risks, or did the Trotskyists just get tired of hearing again and again how dangerous the work was? Whatever it was, they failed to strictly follow the rules for underground work assuming that the Sicherheitspolizei (Security Police, Sipo) had more important enemies to deal with than a little group of Trotskyists. But with Operation Solstice - the wave of arrests on the morning Germany invaded the USSR - the occupier struck them a blow. At least thirteen militants were arrested on that 22 June 1941. Fortunately, the Sipo did not manage to reach the leadership and most of the thirteen had stopped their activity when the occupation began, indicating that the Sipo was working on the basis of pre-war information. ${ }^{39}$ Still, the arrests were a jolt.

Yet watchfulness gradually gave way to routine. What was there to fear from an occupier who reacted to massive strikes in the Liege area by punishing about a hundred strikers by imposing eight days of forced labour on them? The situation was no different elsewhere in Belgium. Jef van der Elst reported how management 'saw no evil' in cases of sabotage for fear of disturbances. ${ }^{40}$

Van der Elst and Mandel spoke fairly regularly. In the margin of a yellowed manifesto Van der Elst wrote, "Drafted and distributed with Mandel's knowledge", silently bearing witness to their intensive co-operation. ${ }^{41}$ Van der Elst was put to work in the EKLA aircraft factory near Deurne. As an apprentice pipe fitter he earned the lowest wage. Luftwaffe aircraft were repaired there. A German colleague taught him how to damage the brakes in a way that would make the plane crash only the third or fourth time it landed. ${ }^{42}$ When he got the chance he went back to work in the shipyards. That was where his heart was, among people who welcomed him as one of their leaders.

In spite of their courage, frivolity and lack of experience eventually took their toll. Ernest Mandel had been living clandestinely since August 1942, longer than other members of the leadership. As long as fellow party members with whom Mandel was in contact continued with their legal lives, the risks remained great. One of them was Camille Loots, whom two Gestapo agents in plainclothes arrested on 4 December 1942 just after his lunch break at his work. Loots worked as an assistant at the Central Fund for Distribution of 


\section{Stutje}

Social and Fiscal Premiums on the Rue Royale in Brussels. Officemates had betrayed him when he had tried too visibly to recruit one of his colleagues for Resistance work. Loots was transferred to the Saint-Gilles jail and interrogated several times at Gestapo headquarters on the Avenue Louise. That same time his home in Sint-Agatha-Berchem near Brussels was searched.

Mandel had been hiding out there since September 1942 and had just left the apartment when the Germans arrived. After leaving he realized that he had forgotten a bag of groceries, turned back and ran right into the Gestapo. Who was he, and what was he carrying in his case? Mandel showed them an identity card with the name Ernest Raes on it and opened the bag, whereupon a bundle of flyers that he had produced with Loots the previous evening fell out. At their Avenue Louise headquarters the Gestapo saw that Mandel's identity card was forged. The address he gave was false as well. An exchange of letters between Referat IV A - the Sipo department specializing in communism and Marxism - and the Wehrmacht jail in Saint-Gilles shows that the prisoner's identity was soon uncovered. ${ }^{43}$ An urgent warning: a Jewish star was drawn with pencil in the margin. In Antwerp the Sipo confirmed that the Cruyslei house had been abandoned for some time; their search turned it inside out.

A small group of comrades, including Albert Clement and Claire Prowizur, met in Brussels. Albert, a 26-year-old mechanic, belonged to cell number 3, in charge of technical and financial tasks. He was responsible for getting paper and printing supplies, paid the full timer workers' wages and supported comrades and their families who had to go into hiding with what little funds were available.

"What it amounts to", said Clement, breaking the silence, "is that they've got Ernest and there's a chance of getting him free." "We need to make contact", he said turning to Claire, "with a woman who has a relationship with the Gestapo and can have some influence on his release. Will you do that?" 44 Clairette was 20 years old and had just married Philippe Szyper, a tailor and member of the PCR's Executive Committee. Both were children of Polish immigrants. They had gotten to know each other in the Brussels branch of the Bund, the non-Zionist Jewish socialist movement affiliated with the Socialist International. The PSR had had Philippe join the Bund in order to make contact with what they called 'interesting elements'. At the age of 17 - "I was sliding gently towards Trotskyism" - Claire had turned her back on Judaism and joined the PSR.

Claire did not know Mandel personally; she had met him once in the woods of Waterloo near Brussels, where comrades held meetings. Two days later, after making an appointment by telephone, she went in the afternoon to the Vleurgatsesteenweg. "She opened the door.... Facing me was a woman who was still beautiful, tall, with curly hair, proud.... She was 40 ; I was 20 . We had only one thing in common: we were both Jewish!" Clairette asked if the other 
woman was able to get in touch with Ernest.

"When she asked, I answered, "Yes, he is Jewish", Claire recalled. "I answered her second question, "Yes, I am too." Claire gave her a hasty description of Ernest: "tall, dark hair, piercing deep eyes, a strong mouth and the hoarse, sarcastic laugh with which he usually ended his sentences". The woman said she would do her best, and told Claire to come back in three days.

In that next meeting the woman claimed to have met Ernest, and confirmed that he was being held not as a Jew but as a political prisoner. Clairette asked about ransom, and for evidence that the person the woman claimed to have spoken with was in fact Ernest. Ernest had two parakeets. Could the woman tell her at their next meeting what the parakeets' names were, and the name of the piece of music that Ernest's mother most liked to listen to? Ernest's father, who was following the negotiations closely, had suggested the two questions.

Henri was in fact leaving no stone unturned in order to secure his son's release. Indirectly he even tried to make contact with von Falkenhausen, the military commander for Belgium and northern France but that attempt led nowhere. This new one seemed more promising, and as soon as there was news he rushed from the place where he was hiding out to Claire's parents' house in order to hear the young Trotskyist's latest report. The woman had demanded a ransom of 100,000 francs, a considerable sum, half of the party's monthly budget. In addition she asked for 30,000 francs in advance.

At the next meeting Claire got the answers to her questions: the parakeets were called Titi and Bibi, and Ernest's mother's favourite piece was Beethoven's Für Elise. The answers were exactly right and Claire handed over the advance and left. The long period of waiting began, for the telephone call that would tell her when and where to hand over the rest of the money. Finally the longed-for message came: the woman asked Claire to bring the money to the now familiar address. "She counted the money and told me, "Tomorrow morning, Ernest will be free." 45

In Saint-Gilles prison cell 159, Ernest was still completely in the dark about the bizarre negotiations in which his fate was the stake. The Sipo interrogated him several times, not only at the Avenue Louise headquarters but also in prison. On 5 January, one month after his arrest, the Sipo picked him up again. Another interrogation on the Avenue Louise? Mandel, surprised, could not imagine what else could be going on. He did not get to see the document that the agents had in front of them: "Ernest Mandel, born 5/4/1923 in Frankfurt-on-Main, most recently resident at 83 Cruyslei, Antwerp-Deurne, held at the facility at this location ... is to be released today and handed over to the signatory of this order." 46 Mandel was handcuffed and sat in the back seat of the car. He recalled:

So before getting there, on Avenue Louise ... where Gestapo 
headquarters was, the car stopped at a crossroads. And I had handcuffs on. What allowed me to escape was that where I was sitting, I mean on the side of the door where I was sitting, the car door wasn't locked.... So I opened the door all of a sudden and jumped, since the car was stopped, and tried to lose myself in the crowd... They ran after me, but they didn't catch me. ${ }^{47}$

If we are to believe Mandel's account, he owed his freedom to his own 'escape'. When asked later about Prowizur's version, the 'ransom', he did not want to hear about it. Documents originally from his father, who in any event came up with the 100,000 francs, confirm that a ransom was paid for Mandel. Coincidence cannot be ruled out, but it seems improbable that a prisoner would be transported in a car with an unlocked door. The Gestapo, whose discipline and accuracy were proverbial, rarely made mistakes like this. Is it not plausible that Mandel's flight was provoked in order to avoid the commotion that was to be expected from an official release? A shortfall in discipline would have been easier to forgive than a corruption scandal.

However that may be, the question as to why Mandel held in public to his own interpretation is none the less fascinating. The least far-fetched reason is probably that Mandel had trouble accepting the fact that his life had been saved, while at the same time the party seemed neither financially nor organizationally capable of helping its Jewish members to go into hiding and obtain false identity papers. Several sympathizers and one or two members had even reported to Mechelen, the initial step in their deportation to Auschwitz. They did not know how to provide for their own safety, and were afraid of being seen as a burden. ${ }^{48}$ Mandel had not exerted the least influence to obtain his own release, yet a stinging sense of guilt kept gnawing at him: why was I spared while they were not?

Moreover, Ernest did not experience his father's intervention as unequivocally liberating. It seemed to underscore his dependence while he was yearning for independence. After the war Mandel felt no inclination to go into details on this complex issue. In 1977 he appealed to Rodolphe Prager, who was delving into the history of the wartime Trotskyist Resistance: "I was able to escape thanks to favours called in by my father... But I ask you to be discrete about the whole question of my biography, because there are still delicate security issues involved." 49

Once restored to freedom Mandel spent fourteen days in the Ardennes, in the village and house where his mother and brother were in hiding. But once he had recovered, he chose the anonymity of the city over the quiet of the countryside. The city provided protection, and gradually the rules for illegal work were being more strictly observed in the Trotskyist party. The finances had become less tight once the technical-financial commission had gone to work. ${ }^{50}$ 
In addition the leadership was situated in Brussels: Abram Wajnsztok (Leon), Optat Henry (Sem), Philippe Szyper, Charles Szatan (Bop), and Widelin (Victor).

Ernest could easily drop in at his parents', who had moved into a substantial patrician house on the Rue Charles Quint in May 1943; with the help of Marcel Devlieghere, chief inspector of the Belgian General Insurance Company Ltd., the house was ingeniously camouflaged as an agency of this important insurance company. While Henri Mandel received clients and offered them the benefit of his advice, the stencil machine in the cellar was kept in readiness to produce the German-language Das Freie Wort ${ }^{51}$ overnight and during weekends, followed by the Flemish-language Vrank en Vrij..$^{52}$ The papers were published until September 1944, and Das Freie Wort, with the subtitle Special Edition for German Soldiers and Wehrmacht Personnel, was so popular that two German soldiers, convinced that fellow soldiers must be putting the paper out, found a way to make contact and offered to help with distribution. ${ }^{53}$ Joseph, a social-democratic employee of the army postal service, managed to fold 'the damned inflammatory rag' into already censored letters from and to German soldiers for four months. Given the risks involved in distribution - copies were thrown into German trucks and left behind in barracks, cafés, and restaurants where soldiers congregated - the paper consisted of only two pages.

In hindsight the enterprise seems as incredible as it was absurd. Michel and his mother may have had false identity papers, but under other names than Henri's. To curious neighbours the story was passed off that Henri Mandel was unmarried, Rosa his sister, and Michel his nephew. They only let themselves be seen on weekends, in the role of visitors who had come to take care of Henri. They spent the rest of the week in the basement, only going out for fresh air as evening was falling. From 1943 on the basement also provided shelter to Rosa's father and her brother Motek as well.

\section{Underground in France}

While Ernest had no 'patriotic' leanings or desire to support the Allied war effort, he contributed regularly to Das Freie Wort. He was responsible for the column called "German poets speak to you", with rebellious verses from the poetry of Schiller, Herwegh, and Goethe meant to undermine morale among Hitler's troops. He also analysed the military theatres of war. ${ }^{54}$ His reports on the extermination camps in Poland were as full of rage as they were alarming:

The Nazi criminals and assassins are killing hundreds of thousands of innocent, defenceless men, women and children, merely because they consider these Poles, Russians and Jews so-called 'subhumans'!... Civilized humanity can 
140 Stutje

and will not tolerate this! Each of you, German soldiers, is complicit unless you rebel against this crime, even if you only keep silent. None of you can use 'orders from above' or your duty as a soldier as an excuse; even in these cases there are lines that a soldier may not cross. Your duty is to put a stop to the activities of the Nazi beasts: rabid dogs must be chained! 55

Along with his propaganda work for the Vrank en Vrij group and for the Trotskyist La Voie de Lénine and its Flemish-language edition Klassenstrijd (Class Struggle), Ernest Mandel got involved in international work. After Stalingrad (November 1942) and the fall of Mussolini, contact with French comrades intensified. In the summer of 1943 a renewed provisional European Secretariat was formed, which developed a plan for an extended European conference in February 1944, open to all organizations that accepted the Fourth International's principles and Transitional Programme. ${ }^{56}$ In November 1943 Ernest Mandel travelled to Paris, accompanied by Paul Widelin.

The conference took place in early February 1944 in Saint-Germain-LaPoterie, near Beauvais (Oise). It was the first international gathering since Trotsky's death in August 1940. Mandel and Leon travelled by way of Paris by train to Beauvais, where they were brought to their destination hiding under the canvas cover of a little pickup truck.

The meeting went on for six days and nights, interrupted only by a few hours' sleep on the floor of an outlying barn. The fire from the hearth warmed only half of the room, so that the fifteen delegates took turns in the warm part. Young militants of the French section guarded them, armed with revolvers. ${ }^{57}$ The debate focused entirely on the approaching European revolution, in which everyone was convinced the German proletariat would play a key role. The events in Italy between July and September 1943 were child's play compared to what was in store for Europe. Once the German working class followed the Italian example, nothing would stand in the way of the long-awaited revolutionary civil war. The Trotskyists shared this analysis after all with Roosevelt, Churchill, and Stalin - though the Trotskyists' feelings at the prospect were of course the opposite of the Allied leaders'. They spent considerable time discussing the importance of campaigns aimed at fraternization with 'German workers in uniform'.

The Trotskyists were optimistic. Few of them doubted the proletariat's ability to form revolutionary parties. Only Mandel and Abram Leon urged caution. Mandel spoke of an international structural crisis of the workers' movement, linked to the workers' low level of consciousness and reformism. ${ }^{58}$ The French comrades rejected the thought as 'un-Marxist'. Mandel was wrongly positing a direct connection between class, party, and leadership so that "if the leadership degenerates, the proletariat has degenerated too". ${ }^{59}$ According to 
Mandel's opponents the defeats were not due to a crisis of the workers' movement, but to a crisis of the revolutionary leadership. Their argument was in keeping with the Transitional Programme. ${ }^{60}$

Yet here lay the Achilles heel of the Trotskyist analysis: the revolutionary perspective was reduced to the short term. What would happen if the mass movement in Europe did not take on an Italian colouration? What if the rhythm and extent of the radicalization in Germany or France lagged behind? What if no new revolutionary parties arose? Was that not a plausible expectation after 25 years of defeats? Fundamentally, fascism and Stalinism were consequences of defeats, not just their cause.

It was logical to keep the tragic fate of the German workers' movement after 1918 in mind, and not only the fate of the victorious Russians. When a revolutionary movement had gotten under way in Germany, the revolutionaries had been completely cut off from the masses; they had spent more than fifteen years embroiled in a fruitless battle against reformism. That situation bore a strong resemblance to the young Trotskyists' circumstances now, in the same isolation and difficulties, and if not as sectarian then at least as weak. If the revolutionaries could decisively influence events, Mandel reasoned, then it was only because:

The stagnation of its movement ... only imposes a more important, more urgent and more complicated task on the young communist high command in Europe than to lead revolutionary movements to victory: the task of rebuilding the entire workers' movement on a new basis, re-educating the masses, and creating the subjective preconditions for a victory after a period of the darkest defeats. ${ }^{61}$

Thus Mandel did not reduce the problem of the so-called subjective factor to the problem of the party or of the party leadership. He was concerned about the restructuring of the workers' movement as a whole.

\section{New Arrests and Deportation}

Until this time the party's centre of gravity had been in Brussels. The party had been only slightly active in the industrial centres of Liege, Antwerp, and Charleroi. In the Centre and Borinage its early influence had evaporated. From this time on work oriented towards the factories and mines of Liege and Charleroi were its central concern. While Mandel took responsibility for Liege, Abram Leon was put in charge of work among the Charleroi miners. In order to be in daily contact, Leon decided to move to Charleroi with his wife Tsica Silberstein (alias Marie).

Solidarity work began during the May 1941 strike in Liege where La Voie de Lénine was passed out at the plant gates of Cockerill, a giant steel company 


\section{Stutje}

with 20,000 employees. The Trotskyists saw the organization of the Liege metal workers as the prototype of the future struggle. The factory committees had organized themselves under André Renard's leadership into a united union (the Mouvement syndical unifié - United Trade-Union Movement, MSU), independent of the Socialist and Communist parties. Afraid of losing its influence in the Liege metal industry - a communist bulwark until 1942 - the Communist Party carried on a campaign against Renard and the paper Travail. The fact that Travail's first issues were printed on the presses of La Voie de Lénine contributed to the communists' hostility. The PCR too came under heavy attack. Mandel recalled, "They went all-out against us in three or four issues of their paper in a row. They dragged us threw the mud, calling us Nazis, fascists, collaborators." 62 It was filth, Mandel said; referring to the murder of Walter Dauge shortly afterwards, he added, "It wasn't enough for them just to argue about politics; they moved on to deeds."

The PCR's influence among the Liege metal workers was, all things considered, limited; it had only a handful of activists. Until the end of 1943 its press had only a few sources: the grapevine of course, the collaborationist and German press, BBC Radio, Radio Moscow, and, after the landing in North Africa, Radio Algiers. By restoring European communications, reports arrived from the better-organized French Resistance. The report that contacts existed between German and US companies via Portugal was a sensational scoop. La Voie de Lénine reported the news and the Trotskyists decided to pass out a bilingual flyer among German soldiers; the gist of it was: "You're being slaughtered, you've been thrown into a shooting gallery, while the real masters of Germany are negotiating and saving their ill-gotten gains." 63

No record survives of how long they kept distributing their paper and flyers on the Rue Jean in Seraing; but the Gestapo must have caught them by surprise. Only Optat Henry managed to get away; for Mandel there was no chance of escape. Over a month before the European conference, he was a prisoner for the second time. A day after his arrest on 29 March he was transferred to the Saint-Léonard prison near the Liege Citadel. A month and a half later came his trial. Paradoxically, he had the good fortune to be charged with undermining the Wehrmacht. This meant that he fell under military jurisdiction rather than the SS. Before the court martial of the Liege Higher Field Command he was sentenced on Friday morning, 12 May 1944 to two and a half years of hard labour. As he was brought back to his cell Mandel enjoyed the pleasure of hearing his German guards talking about the flyer text that had been brought in evidence against him: "Just the same that was really interesting what was in that thing. You think it's true?" ${ }^{44}$ It was a comfort to have sowed doubts among at least a few subjects of the German Reich.

Indirectly Mandel wrote to his parents that he was "full of good spirits, healthy and well.... But of course I suffer as I think about my poor parents.... If 
only I could know where my dear little mother is - but alas, I am totally in the dark! - then I would beg her to stay strong and well." ${ }^{65}$ With these lines he made clear in coded language that he had not given away the address on the Rue Charles Quint. The Germans were evidently interested in the Vrank en Vrij group, not in the Fourth International. Again in the last note Mandel wrote before his deportation, he warned in a foolish-sounding passage that his parents had played an important role in the interrogations: "Two weeks ago an SS Obersturmführer told me that they are all together in Auschwitz in Upper Silesia, and that my father is doubtless working at his profession there. I was very glad to hear it." $" 66$

After his sentence, prison conditions became less harsh. He could receive packages and write letters and was allowed to have visitors. He intensified his reading of Verlaine, Rimbaud, and Melville. On the evening before his transport left he was full of self-confidence, only a little melancholy: "the heart can be troubled and the mind can digress; but my unshakable will remains and says, 'Patience. Everything comes to an end eventually. ${ }^{67}$... And I will wait...." 68

It had been agreed that Abram Leon would monitor the work in Charleroi. Two weeks after Mandel was sent off on his transport, Leon and his wife set off to Charleroi. That evening they reported to the house of the 28-year-old Olivia Ruland, alias Yvonne. In the course of the evening several other comrades trickled in: little Jules Henin, over 50 years old, with blond hair and the majesty of a patriarch, and Florent Gallois, like Henin a former mineworker. There was also an escaped Russian prisoner of war who had worked in the mines and found a place to hide in Yvonne's house. The house was full of clandestine literature, money, a radio, propaganda material, and printers' supplies a casual carelessness that was characteristic of the attitude with which illegal work was done.

"Aufmachen! Aufmachen!!” [“Open up! Open up!!”] Before Yvonne even had the door completely open, the German Military Police were inside. It was past midnight and the Germans were doing a blackout check. They had noticed a chink of light shining out the window. As soon as the noise reached them, Henin, Gallois, and, Leon's wife, Tisica ran out a back door. Leon and the Russian escapee were in bedrooms upstairs. The soldiers found suspicious materials everywhere. They called immediately for reinforcements, and proceeded to search the house for four hours. Leon admitted in his first interrogation that he was a Jew and in hiding. Yvonne, Leon, and the Russian were taken off to jail.

Long days of physical and psychological torture followed. Leon denied being politically active. ${ }^{69} \mathrm{He}$ managed to win the confidence of a guard, who helped him smuggle notes to fellow party members. He urged them without resentment to be extremely careful: "Your own skin will not feel the effects of 


\section{Stutje}

your carelessness; someone else's skin will., ${ }^{, 70}$ A plan was set in motion to free Leon. They had to work fast. Leon warned that Yvonne could not stand the torture any more. ${ }^{71}$ The SS threatened "if I didn't talk, they'll beat me to death", and he added, "they're capable of keeping their promise. Do everything to organize the escape." $" 72$ Leon asked for fast-acting poison.

On Tuesday, 20 July he wrote his last lines. He suspected he would be transferred to Mechelen: "I hope you will do everything to keep the cause from being set back too much by my departure.... I don't know what fate awaits me, but you should know that whatever happens, my last cry will be: Long live the Fourth International!"73 By way of Mechelen Leon was put on a transport to Auschwitz.

Mandel and Leon had spent several intense years with each other. They were two boys who had left a Jewish community without renouncing their origins. They found the contradictions of modern society - between rich and poor, powerful and powerless, and the apparently unbridgeable abyss between Jews and foreigners on the one hand and the outside world on the other unbearable, and each turned to rebellion according to his own experience. One of them came into contact with German political refugees, the other with the left-wing Zionist youth movement; they tried to understand the world on the basis of the notion of class struggle. This helped them to leave family ties and respect for authority behind them. As Mandel expressed it, their minds liberated their characters. They learned to put them in service of a single goal: the struggle for socialism. Their individual wills merged with that ideal; and the harder they were tested in the war years, the more fiercely they resisted.

They shared an aversion to chauvinism, including its left-wing Zionist version but they were equally determined in their opposition to indifference to the national question. Their internationalism in no way ruled out participation in the struggle of the oppressed against an occupier. Now both had becomes victims of that struggle, and neither knew of the other's fate. Leon added a P.S. to his last note to be smuggled out of jail: "I count on you to publish, as soon as circumstances make possible, my work on the J[ewish] Q[uestion], which is very important to me." "74 Immediately after the war Edition Pionniers in Paris published the posthumous Jewish Question: A Marxist Interpretation. Under the pen name Ernest Germain, Mandel wrote a moving biographical sketch of the comrade-in-arms whom he considered his teacher.

\section{Towards the Liberation}

When he was deported to the Third Reich in the spring of 1944 in the company of nine other prisoners, Mandel began a journey that would take him to halfa-dozen prisons and work camps. The fact that he came out of it alive has to be 
considered a miracle. As a Resistance fighter, a Jew, and a Trotskyist despised by Stalinist fellow-prisoners, his chances of survival were minimal. He said himself:

I shouldn't exaggerate because there was just good luck in it too. But ... I did not behave like most of the Belgian and the French prisoners who were very anti-German. I deliberately looked for politically sympathetic warders. That was the intelligent thing to do even from the point of view of selfpreservation..$^{75}$

In the Hürtl-Wesseling work camp near Cologne the guards were not SS members, as they were in the concentration camp, but regular prison guards, some of whom had been in the profession since the 1920s. Quite a few of them had social democratic pasts, Mandel remarked. He also found kindred spirits under German fellow prisoners. He made contact with the son of a socialist railway worker from Cologne, who - once his confidence had been won - gave Mandel his father's address, assuring Mandel that his father would help him if he managed to escape. In this way Mandel's plan to get away took shape.

Mandel was put to work at IG Farben, one of Germany's biggest chemical complexes. About 60,000 workers - Russian and Western prisoners of war, political prisoners and forced labourers from concentration camps, and civilian workers from Germany itself - kept production of synthetic petrol going there for the war machine. It was a microcosm of European society under Nazi rule. In an earlier camp he had been put to work as an assistant nurse; here the work took a heavier toll on him. He had never done hard physical labour before. After a number of Polish prisoners found out that he was Jewish, only a priest's intervention stopped the anti-Semites from murdering him. He wrote home:

Convict labour is a great school of stoicism and patience, and God knows if I had needed a good lesson in them. One gets a more accurate sense here of the true value of things; much that one had once thought of as essential sinks into insignificance, and the truly precious things appear with luminous clarity. I think - I'm convinced of this - that I will not only leave the prison camp more serious and chastened, but also that many of my character defects will have disappeared. ${ }^{76}$

With help from Belgian fellow prisoners, Mandel succeeded in getting hold of gloves and trading in his prison uniform for civilian clothes. He had noticed that the power for the electrified fence was temporarily turned off during the changing of the guard. He decided to take the risk. He climbed over the barbed wire and disappeared into the forest. It was an insane endeavour, with a 99.9 percent chance that he would be shot dead on the spot if his escape failed. He enjoyed his freedom for one day. He was captured the next morning on the way to Aachen, in the forest near the Belgian border. Because he did not 
146 Stutje

give the name of the camp he had escaped from he was brought to the prison in Siegburg, where he was beaten for two weeks and chained in the dungeon with a couple of slices of bread as his only food. Finally he gave the name of the camp and was led before the commandant. Mandel still remembered the commandant's confusion 25 years later: "YYou are a rare bird. Do you know that if you had been brought back you could have been immediately hanged?' I said yes. So he just looked at me in total amazement."77

The tensions had not left Mandel unaffected. Since the beginning of the occupation he had had eczema breaking out on his legs from time to time. He was terribly thin and had heart palpitations. Being dragged from camp to camp aggravated his condition further still. He was put in the sickbay at Eich with hunger oedema. On 25 March 1945 the Americans freed him in Niederroden.

Despite his joy at being freed, Mandel also had doubts. Would he find his family come safe and well out of hiding? What about the long-awaited German revolution? Would his hope be fulfilled or turn out to be merely a dream? The hoped-for revolution had kept Mandel going: "I was almost happy to be deported to Germany. I was full of a mad confidence: I was going to be at the centre of the revolution". ${ }^{78}$

In the Rue Charles Quint in Brussels, Mandel's parents were ignorant of their son's fate. No one knew if he was still alive or if so where he was. On 26 April the Repatriation Office reported that they could find no trace of him. They were speechless when Ernest came to the door that very same afternoon. He had come by train from Darmstadt in soldiers' shoes, terribly thin, and in shabby clothes without underwear or an overcoat. He had worked as an interpreter for his liberators for almost four weeks, and helped with repatriation of political prisoners. He had made a good recovery, to judge from a letter [in English] that arrived after he did:

I will come back with a 'headful' of material to write, write and write and all what I saw, heared [sic] and lived only stiffened me in my convictions. I am so impatient about getting on working again - please try to get some information about facilities for University examinations for students in my case. $^{79}$

The family had made it whole through the war - even Rosa's old father and brother Motek were alive - but they were anything but happy. ${ }^{80} \mathrm{~A}$ shadow hung over them because of the evil that had been done to Henri's mother, sister, and brother in Auschwitz.

People who had returned from the camps or kept out of the Gestapo's clutches felt little inclination to dwell on the past. "You really can't want me to keep telling you about the Nazi terror", wrote Henri; ${ }^{81}$ the Mandels found dredging up the memories painful. Ernest too preferred to forget about the war. On the day that Nazi Germany surrendered, he made an exception for Gina, his 
father's sister who had emigrated to Palestine in 1926:

Worst of all were moral conditions of life, the compulsion to live on false papers, to hide oneself, to remain indoors when it was not absolutely necessary to leave, the absence of all connections with free world and free thought. The only luxury we enjoyed was the wireless which we used to listen to from morning to night.

As to my life in German prison camps, I must say I have never been beaten or ill-treated. Nevertheless, conditions of life were very unsatisfactory, mainly because of lack of food, hard work - especially for a student like me who never used to do manual work - and all kind of moral chicanes [sic]: we had all our hair cut, we were not allowed to read or to write, we had no water to wash for 4 months, we were to execute some very dirty jobs, were commanded by criminals and so on. I lived in this atmosphere for 14 months. ${ }^{82}$

Ernest did not go into much more detail than this. He had the future in front of him, not behind him; there were more urgent matters that demanded his attention.

\section{Epilogue}

After the war Ernest Mandel devoted himself to building the Fourth International and forming a revolutionary tendency inside Belgian social democracy. He took part, on André Renard's behalf, in a study commission of the General Belgian Trade Union Federation charged with developing an alternative to the power of the big financial conglomerates which produced a programme for anti-capitalist structural reforms that became a platform for the Belgian general strike in the winter of 1960-61.

In the meantime he finished his studies at the Free University of Brussels and began his research on trends in the development of modern capitalism. In 1962 he published Marxist Economic Theory, followed ten years later by his magnum opus: Late Capitalism which the free University of Berlin accepted as a dissertation. Revolutionary politics and scholarship were the pillars on which Mandel sought to build a new Babylon, and which he enriched with his unorthodox insights in the best tradition of the Marxist workers' movement.

From an early age Mandel struck people because of his talent, creativity, and strong sense of justice. School and his family's Jewish, left-wing socialist milieu directed his tempestuousness and rebelliousness against the outside world. With the rise of fascism and Stalinism darkness descended on that outside world. Neverthless, he could still rely on the care of his doting parents and political friends. They transmitted to him their love for scholarship and art, and 
acquainted him, in the era of the Spanish Civil War and Moscow Trials, with solidarity and resistance. He learned to understand the world on the basis of those ideas, and to look for connections that allowed him to give form to his high aspirations. Life in the midst of revolutionary exiles inspired in him an internationalist vision against which his cultural and ethnic background remained visible. Mandel preferred to characterise himself as a 'Flemish internationalist of Jewish origin'. This characterisation stamped him as, to borrow Isaac Deutscher's expression, a 'non-Jewish Jew': a heretic moving along the frontier of different civilisations and cultures, whose thinking transcended the level of his own society. ${ }^{83}$

The occupation strengthened Mandel's internationalist convictions - not least through his contacts with German soldiers, guards, and fellow prisoners who helped him survive the Nazi camps. The Nazi terror forced him to become conscious of his Jewish and Flemish roots. Together with Abram Leon, he defended the occupied and oppressed peoples' right to self-determination without swallowing his criticisms of the Allies or joining in the official Resistance that made the proletariat dependent on its own bourgeoisie. Mandel's contributions to debates on the national question, revolutionary strategy, Stalinism, and the Holocaust were among his most remarkable writings in those years.

In another respect as well, the Trotskyist movement was less marginal than its small size suggested. Trotskyist sympathizers correctly identified the farreaching social and political consequences of the war. Trotskyists' hopes of forcing a breakthrough towards a new, global party of revolution, an alternative to the Second and Third International, were another matter. Mandel was one of the few to warn of the optimism bordering on illusions of his fellow party members. He feared that Trotskyists were underestimating the impact of 20 years of defeats on the consciousness of the European workers' movement.

Mandel's scepticism cannot be understood in isolation from the growing pains of the Trotskyist movement in Belgium. The PSR/PCR's quick recovery was thanks to the young, energetic group of members recruited in the late 1930s that included Ernest Mandel and other Jewish immigrants. But their numbers could not compensate for the loss of hundreds of mineworkers in the Borinage. Moreover, they were vulnerable to the anti-Semitic repression that affected many people in Trotskyist circles after 1942. Organisational naiveté and risky activities further increased Trotskyists' vulnerability. When the mass movement in Europe came to life in 1943 and later and the European revolution seemed to be taking great leaps forward, Trotskyists could not respond. At the moment of the Liberation in 1944, the arrests of Leon, Widelin, and Mandel had left the PCR decapitated. Roughly a hundred leaderless Trotskyists were not capable of having the least influence on the course of events. The masses were disinclined towards a revolutionary solution. They preferred to take up the Communist Party's slogans, and from 1947-48 on the Socialist Party's. 
Paradoxically, the post-war regroupment around social democracy ultimately gave Trotskyists a foothold they could use to pull themselves up out of their crisis. After entering the SP Trotskyists turned their efforts towards forming a left wing, which oriented in the second half of the 1950s towards the weeklies La Gauche and Links. Ernest Mandel played an inspiring role in both. With him the Belgian section of the Fourth International took the stage like a rejuvenated phoenix in the lively left of the 1960s.

Grateful thanks to Dr. Rudi Van Doorslaer for his critical comments. Thanks to Anne Mandel-Sprimont, Professor Michel Mandel, Willy van der Helst, and Jan Debrouwere for their willingness to share their memories with me. This revised article, translated by Peter Drucker, appeared previously under the title "Ernest Mandels kleine oorlog: Revolutionaire socialisten in bezettingstijd, 1940-1945," Cahiers d'Histoire du Temps Présent/ Bijdragen tot de Eigentijdse Geschiedenis 12 (November 2003): 7-49.

\section{Notes}

${ }^{1}$ Frankfurter Allgemeine Zeitung, 21 July 1995.

2 Ernest Mandel's extensive archive has been housed since 1996 in the International Institute for Social History in Amsterdam.

${ }^{3}$ See Jan-Willem Stutje, De man die de weg wees, Leven en werk van Paul de Groot 1899-1986 (Amsterdam: Bezige Bij, 2000), 314.

${ }^{4}$ Interview with Ernest Mandel (Collection Jours de Guerre, SOMA, AA 1450).

${ }^{5}$ Conversation between Rodolphe Prager and Ernest Mandel, 12 November 1977 (IISH Amsterdam, R. Prager Archive, 270).

6 "Recollections of Ernest Mandel," De Internationale 39, no. 55 (Autumn 1995), 21. ${ }^{7}$ Albert Glotzer, Trotsky: Memoir and Critique (New York: Prometheus Books 1989), 195.

${ }^{8}$ Ernest Mandel to Walter Besser, 9 December 1991 (IISH Amsterdam, E. Mandel Archive).

9 "Lion Feuchtwanger über den Prozesz, Moskau 30. Januar," Rundschau 6, no. 5 (1937).

10 Henri Almond [Henri Mandel], Der Schutzgeist der Stalinschen Justiz, Eine Abrechnung mit Lion Feuchtwanger, February 1937 (Trotsky Archive: The Houghton Library, bMs 13.1 [17185]).

11 Jules Gerard-Libois and José Gotovitch, L'An 40: La Belgique occupée (Brussels: Editions du CRISP, 1971), 105.

12 Cited in Marc Lorneau, Contribution à l'histoire du mouvement trotskyste Belge, 1939-1960, vol III (Liège: n.p., 1983), 273.

13 Joseph to "mon cher Stuart," 1 May 1940 (R. Prager Archive, 143).

14 Renaud Lefèbvre, Dauge et le daugisme, Une page de l'histoire du mouvement 
$150 \quad$ Stutje

ouvrier dans le Borinage (Brussels: n.p., 1979), 83.

${ }^{15}$ Interview with Ernest Mandel (Marc Lorneau, Contribution à l'histoire, 3: 281, 301).

${ }_{16}$ José Gotovitch, Du Rouge au tricolore, Résistance et parti communiste (Brussels:

Editions Labor, 1992), 97.

${ }^{17}$ Interview with Ernest Mandel (Collection Jours de guerre, SOMA, AA1450).

${ }^{18}$ Pierre Broué, Trotsky (Paris: Fayard, 1988), 808.

${ }^{19}$ In our opinion Lieven Saerens was mistaken to characterize Het Vrije Woord as a Trotskyist paper. Lieven Saerens, Vreemdelingen in een wereldstad, Een geschiedenis van Antwerpen en zijn joodse bevolking (1880-1944) (Tielt: Lannoo, 2000), 670.

${ }^{20}$ Het Vrije Woord, October 1940, no. 1 (Henri Mandel, "Hun taak en de onze").

${ }^{21}$ Het Vrije Woord, November 1940, no. 2 (Ernest Mandel, "De sluipmoordenaar van Mateotti delft zijn eigen graf').

${ }^{22}$ Het Vrije Woord, November 1940.

23 André Uyttenbrouck and Andrée Despy-Meyer, Les cent cinquante ans de l'Université libre de Bruxelles (1834-1984) (Brussels: Éditions de l'Université, 1984), 38-47.

${ }^{24}$ Het Vrije Woord, December 1941.

${ }^{25}$ Conversation between Jan-Willem Stutje and Willy van der Helst, 28 May 2002.

${ }^{26}$ Claire Prowizur, Conte à rebours, Une résistante juive sous l'occupation (Brussels: Louis Musin, 1979), 160.

27 Johanna Pezechkian, "La Möbelaktion en Belgique," Cahiers d'Histoire du Temps Présent' Bijdragen tot de Eigentijdse Geschiedenis, 10 (2002).

${ }^{28} \mathrm{SD}$ records (Dienst voor de Oorlogsslachtoffers, Brussels).

29 "The luck of a crazy youth: Ernest Mandel interviewed by Tariq Ali," The Legacy of Ernest Mandel, ed. G. Achcar (London: Verso, 1999), 220-21.

${ }^{30}$ Meir Yaari, "L'Hachomer-Hatzair. Hier et Aujourd'hui," Cahiers Bernard Lazare (November 1967).

${ }^{31}$ Quatrième Internationale, 5-7 (July 1953).

${ }^{32}$ Abram Leon, The Jewish Question: A Marxist Interpretation (New York: Pathfinder, 1970), 18-19.

${ }^{33}$ Rik Hemmerijckx, "De KPB, haar syndicale strategie en haar verhouding tot het renardistisch syndicalisme (1940-1944)," Vlaams Marxistisch Tijdschrift, 21, no. 1 (March 1987), 36; Cf. Rik Hemmerijckx, Syndicaat in oorlog. De socialistische vakbeweging in oorlogstijd en de ontstaansgeschiedenis van het Renardisme (1940-1945) (Brussels: n.p., 1985).

${ }^{34}$ Rudi Van Doorslaer, "Israel (Piet) Akkerman, de diamantzager (1913-1937), Een joodse militant van de Derde Internationale in Antwerpen," in BTNG-RBHC XXII (1991), 3-4.

${ }^{35}$ Conversation between Rodolphe Prager and Ernest Mandel, 12 November 1977 (R. Prager Archive, 290).

${ }^{36}$ Clara and Paul Thalmann, Revolution für die Freiheit, Stationen eines politischen Kampfes (Grafenau-Döffingen: Trotzdem, 1987), 334. 
${ }^{37}$ Harry Ratner, "Report on the PCR, Belgian section of the Fourth International, 18 January 1945," in Revolutionary History 7, no. 1, (1998).

${ }^{38}$ E. R. (Ernest Mandel), "Les Taches du parti et la montée révolutionnaire," in Intern bulletin. Cuisinez à l'électricité, propreté! Confort! Économie! April 1943 (R. Prager Archive, 146).

${ }^{39}$ Marc Lorneau, Contribution à l'histoire, 3: 350-51. José Gotovitch, Du Rouge au tricolore, 138.

40 Jozef van der Helst, Rapport over de industriële kontra resultaten voor de NaziDuitse oorlogseconomie op het werkhuis The Engineering in de jaren 1940-1944, n.d. (SOMA, AA 902).

41 Open Letter, Aan Alle Arbeiders. Wij zwijgen niet, signed K. Marx, n.d. (1943) (SOMA AA 902).

42 Conversation between Jan-Willem Stutje and Willy van der Helst, 28 May 2002.

${ }^{43}$ Der Militärbefehlshaber für Belgien und Nordfrankreich M V CH. Der Beauftragte des Chefs der Sicherheitspolizei und des SD für Belgien und Frankreich an das Wehrmachtsuntersuchungsgefängnis Sint-Gilles, 8 December 1942, in Dossier Ernest Mandel, Dossiers E 15032/517/483, Dienst voor de oorlogsslachtoffers.

44 Claire Prowizur, Conte à rebours, 65. Interview with Claire Prowizur-Szyper (Collection Jours de Guerre, SOMA AA 1450).

${ }^{45}$ Claire Prowizur, Conte à rebours, 71.

46 An das Kriegswehrmachtsgefängnis St. Gilles, 5 January 1943 (Dossier Emest Mandel, Dossier 33446, Dienst voor de Oorlogsslachtoffers).

${ }^{47}$ Interview with Ernest Mandel (Collection Jours de Guerre, SOMA AA 1450).

48 Claire Prowizur, Conte à rebours, 48, 56. Interview with Albert Clement, cited in Marc Lorneau, Contribution à l'histoire, 3: 389.

49 Emest Mandel to Rodolphe Prager, 2 October 1977 (R. Prager Archive, 290). Conversation between Rodolphe Prager and Ernest Mandel, 12 November 1977 (R. Prager Archive, 290).

50 The party acquired the lion's share of its income through producing and selling false identity papers on the black market, illegally printing food coupons, and misappropriation of funds through embezzlement and robberies.

${ }^{51}$ A total of 21 issues of Das Freie Wort were published, with average print runs of 4000 copies. (Report on Das Freie Wort, Léo Lejeune Archive, SOMA, AA 756.)

52 Seventeen issues of Vrank en Vrij were published with an average print run of 4300 copies. The paper was also distributed in Antwerp, Mechelen, Louvain, Turnhout, Ghent and Oostend. It was delivered to local distributors in leather pouches with secret compartments. (Report on Vrank en Vrij [Henri Mandel Archive (A. MandelSprimont)].)

${ }^{53}$ Report on Das Freie Wort (Léo Lejeune Archive, SOMA AA 756).

${ }^{54}$ Das Freie Wort, May 1943.

${ }^{55}$ Das Freie Wort, September 1943.

56 Rodolphe Prager, Les congrès de la Quatrième Internationale, vol. 2: L'Internationale dans la guerre 1940-1946 (Paris: Editions La Brèche, 1981), 115.

${ }^{57}$ Ibid., 183. Yvan Craipeau, Contre Vents et Marées, Les révolutionnaires pendant la deuxième guerre mondiale (Paris: Savelli, 1977), 247. Jacqueline Pluet-Despatin, Les 


\section{Stutje}

trotskistes et la guerre 1940-1944 (Paris: Anthropos, 1980), 154.

${ }^{58}$ E. R. (Ernest Mandel), "La crise mondiale du mouvement ouvrier et le rôle de la IVe Internationale," Quatrième Internationale 3 (January 1944).

${ }^{59}$ A. J. (Rodolphe Prager \& Marguerite Bonnet), "La crise de la direction révolutionnaire, unique cause des défaites de la Révolution mondiale," Quatrième Internationale, 6-7 and 8-9 (April-May and June-August 1944).

${ }^{60}$ Trotsky had supplied the Fourth International with the Transitional Programme when it was founded in 1938. The document bore the revealing title, The Death Agony of Capitalism and The Tasks of the Fourth International. It argued that the social democratic and Stalinist leaderships of the workers' movement were blocking the clean-up of capitalism. It was up to revolutionaries to resolve this key problem.

${ }^{61}$ E. R. (Ernest Mandel), "La crise mondiale du mouvement ouvrier et le rôle de la IVe Internationale," Quatrieme Internationale 3 (January 1944).

62 Interview with Emest Mandel (Collection Jours de Guerre, SOMA, AA 1450).

${ }^{63}$ Ibid.

${ }^{64}$ Ibid.

${ }^{65}$ Ernest Mandel, 14 May 1944 (H. Mandel Archive).

${ }^{66}$ Ernest Mandel, 2 June 1944 (H. Mandel Archive).

${ }^{67}$ Ibid. "Everything comes to an end eventually" - in German in an otherwise French text.

${ }^{68} \mathrm{Ibid}$.

${ }^{68}$ Correspondance, 24 June-20 July 1944 (E. Mandel Archive, Letter 2).

${ }^{70}$ Ibid. (E. Mandel Archive, Letter 3).

${ }^{71}$ Ibid. (E. Mandel Archive, Letter 6).

${ }^{72}$ Ibid. (E. Mandel Archive, Letter 6).

${ }^{73}$ Ibid. (E. Mandel Archive, Letter 7).

${ }^{74}$ Ibid. (E. Mandel Archive, Letter 7).

75 "The luck of a crazy youth," 222.

${ }^{76}$ Ernest Mandel to "Lawyer," 6 August 1944 (H. Mandel Archive).

77 "The luck of a crazy youth," 223.

${ }^{78}$ Conversation between Rodolphe Prager and Ernest Mandel, 12 November 1977 (R. Prager Archive, 270).

${ }^{79}$ Ernest Mandel, 18 April 1945 (H. Mandel Archive).

80 "Our feeling of happiness is very much dimmed", Henri Mandel wrote to Hector Goldman, 31 July 1945 (H. Mandel Archive).

${ }^{81}$ Henri Mandel to Maurice Piller, 12 December 1945 (H. Mandel Archive).

${ }^{82}$ Ernest Mandel to Gina Triffon, 8 May 1945 (H. Mandel Archive) [in English in the original].

${ }^{83}$ Isaac Deutscher, The Non-Jewish Jew and Other Essays (London: Oxford University Press, 1968). 